تدوين يك مدل فازى بهينهازى الكوى كشت و تخصيص آب بر مبناى تئورى بازىهاى همكار انه، مطالعه موردى: كانال اردبيهشت شبكه آبيارى درودزن فارس

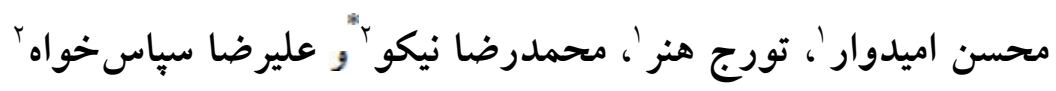

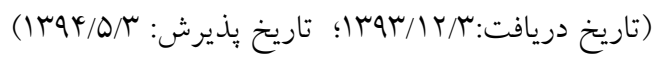

جكيده

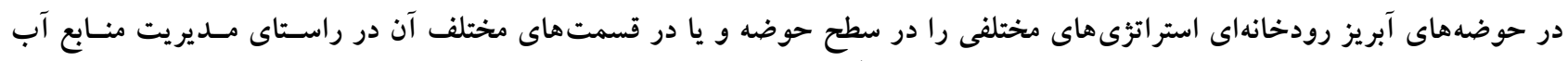

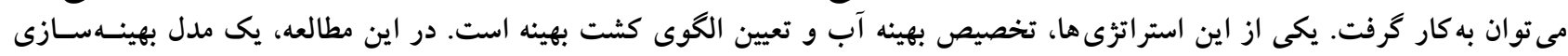

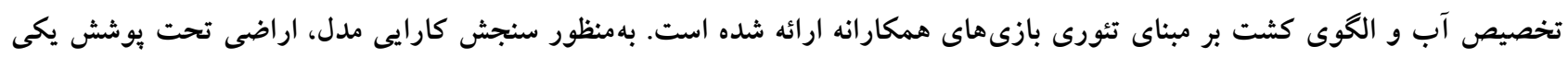

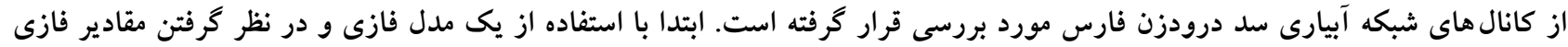

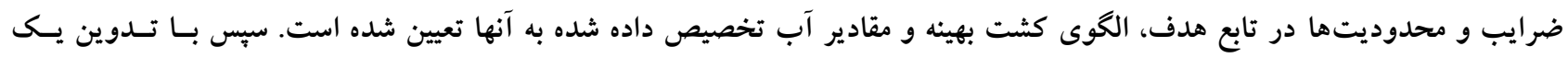

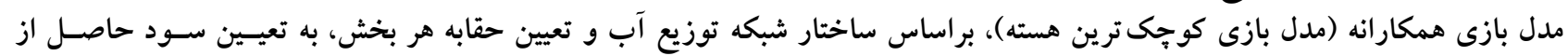

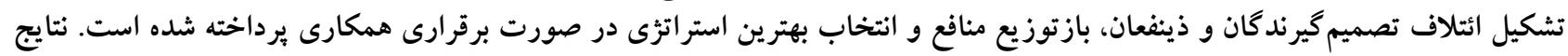

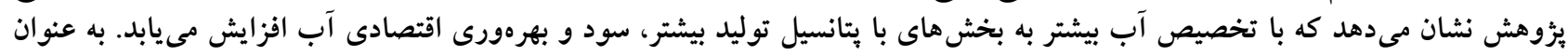

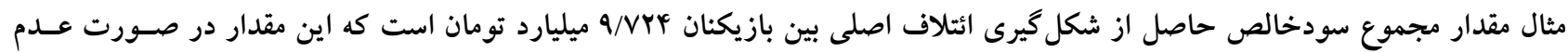

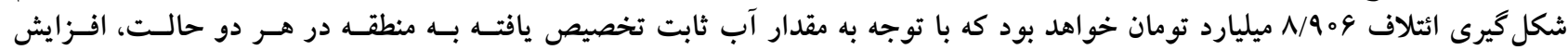

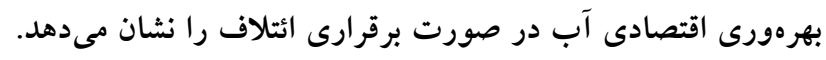

كلمات كليدى: بهينه سازى الكوى كشت، تخصيص بهينه آب، مدل فازى، بازى همكارانه

ا. أكروه آبيارى و زهكشى بخش مهندسى آب، دانشكده كشاورزى، دانشكاه شيراز

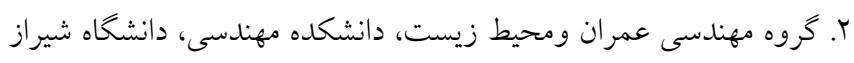

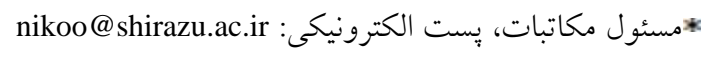


مترمكعب آب و هر كيلو گرم كود لحساظ كرديسـه اسـت. نتـايج

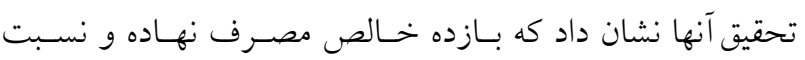

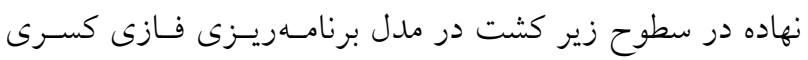

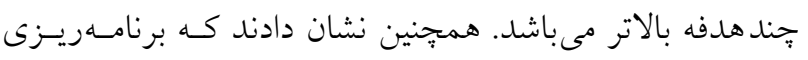

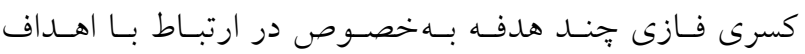
اقتصادى و محيط زيستى، ابزار مناسبى براى تعيين الكوى بهينـه

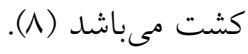

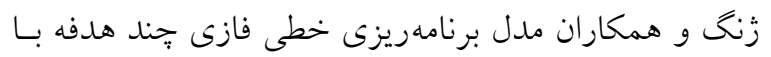

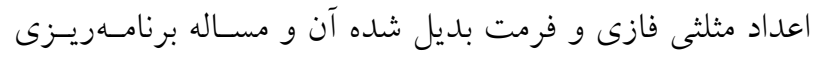

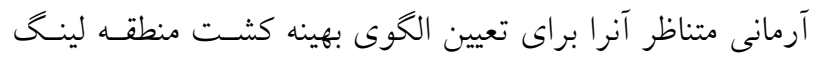
زائو در استان كانسو واقع درشمال غربى جين ارائه دادنـــ (TV).

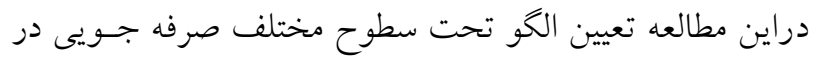
آب و درجات رضايتمندى تصميم گيران از در دسترس بـودن

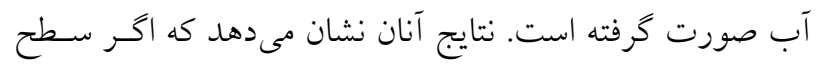

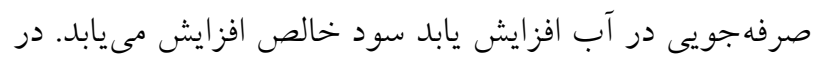

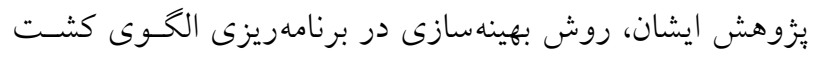

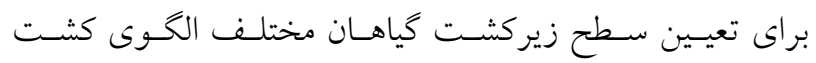

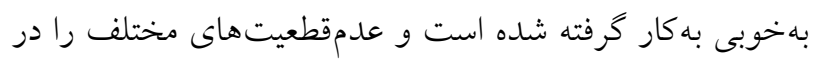

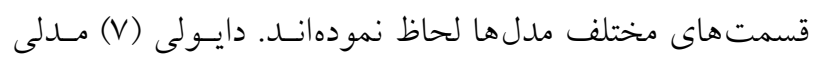

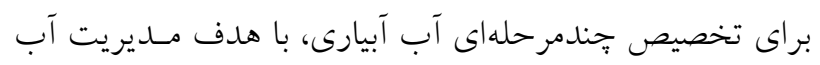

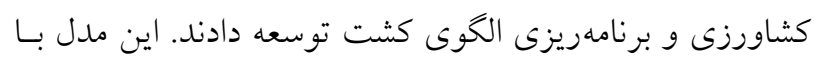

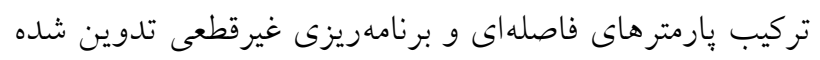

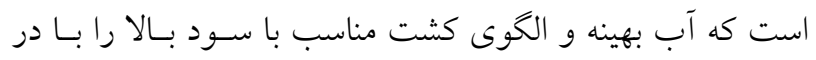
نظر كرفتن پايدارى منابع آب تعيين مى كند.

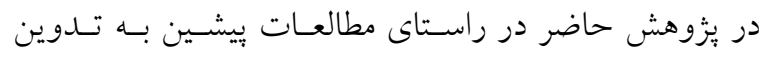

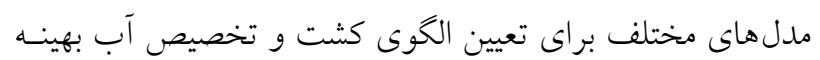

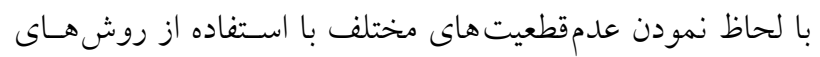

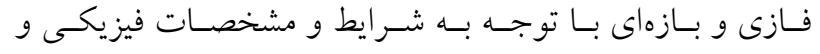

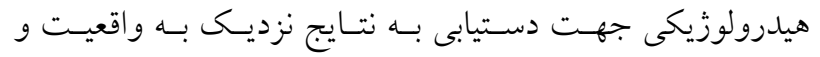
كاربردى يرداخته شده است. عمق بارش مـوثر، ضـرايب سـود و

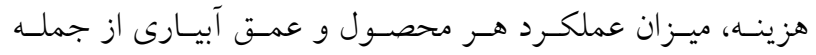
يارامترهايى كه عدمقطعيت آنها در مدلها وارد گرديده است.
امروزه يكى از راهكارهاى اساسى جهت مــيريت و تخصسيص منـابع آب آبيـارى، انتخــاب الخـوى كشـت مناسـبـ وتعيـين استراتزىهاى تخصيص بهينه آب آبيارى مىباشد كـه درشـرايط محدود بودن منابع آب و فراوانى اراضسى قابـل كشـت، هـدف مى بايست افزايش كارايى مصرف آب و اسـتفاده بهينـه ازمنـابع

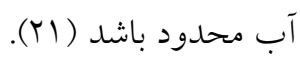
در شرايط دنيـاى واقعى و در بسـيارى ازمسـائل عملىى،

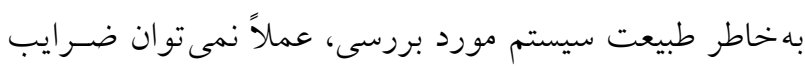
و متغيرهاى تابع هدف مدلهـاى بهينـهسـازى را بـهـصـورت اعداد صحيح، قطعى و دقيـق در نظـر كرفـت. جـــرا كـه اولاً توابع استفاده شده بهصورت دقيق و صريح تعريف نشــدهانــ و يا طبيعت مساله تصميم گيـرى فقـط بــا روش فـازى قابـل تشريح است، بهعنوان مثال عبارتهايى نظير ((تقريباً مسـاوى

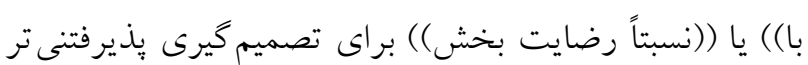

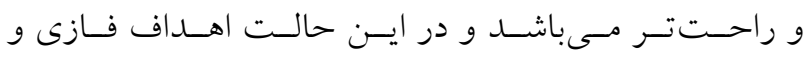
محدوديت هاى فازى مناسبتر خواهند بود. ثانياً عدم قطعيت و غيرصريح بودن يديدههاى موجود در جهـان و محــدوديت

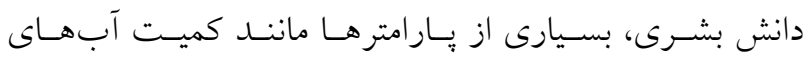
سطحى، ميزان محصول گياه، قيمتها و حجم آبيارى، قطعى و مشخص نيستند (TV). در تعيين الكوى كشت بهعنوان يـك مسـأله تصـميم گيـرى،

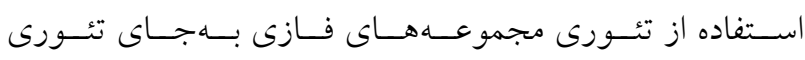
مجموعسههـاى كلاسـيك كـاراتر اسـت ومــدل برنامسهريـزى و بهينه سازى قطعى، براى تصميم گيرى در جنين محيط غيرقطعى مناسب نمىباشد. در اين زمينه يـرَوهش هــاى مختلفى صـورت كرفته است كه در هر كدام به طريقى كوشـيده شـده اسـت كـهـ تمام يـا برخـى از عـدمقطعيـت هــاى موجــود را بــا اسـتفاده از روش هاى مختلف اعمال كنند ( ا، Y و YV). دانشور كـاخكى از مدلهاى برنامهريزى خطى و برنامسهريـزى فـازى جنــ هدفـه كسرى براى بيداكردن الكوى بهينـه كثـت در شهرسـان تايبـاد استفاده كردند. دراين مطالعه اهـــاف حــــاكثرسـازى بــازده هـر 
تئورى بازىها و استفاده از آب براى بخش كشـاورزى و تعيسين

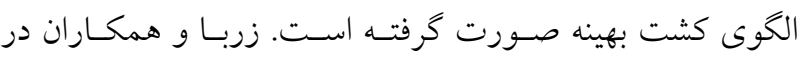

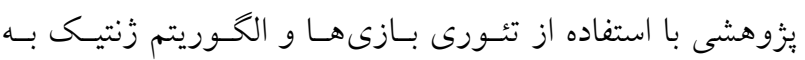

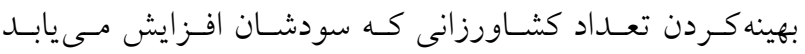

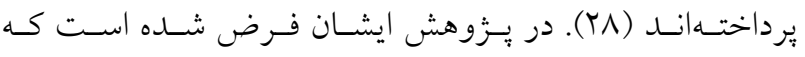

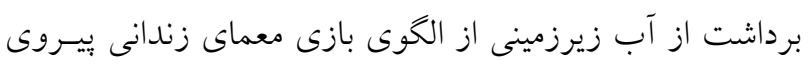

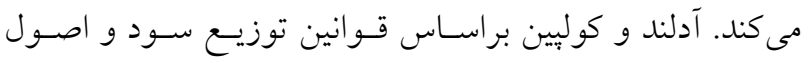

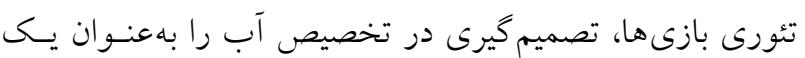

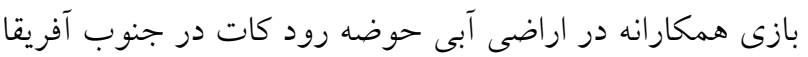

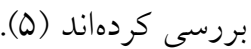
در يزوهش حاضر براى نخستين بار در زمينه تعيين الكــى

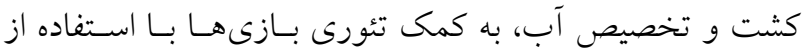
روش بازى همكارانه به بازتوزيع سـود حاصـل از شـكل گيــى لهـ

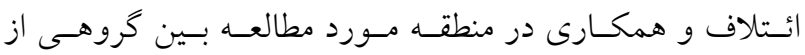

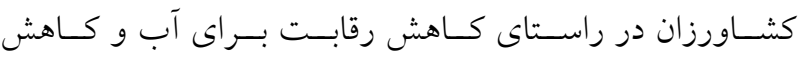
اختلافات استفاده شده است. ابتدا مقادير سود فازى مربـوط بــــ

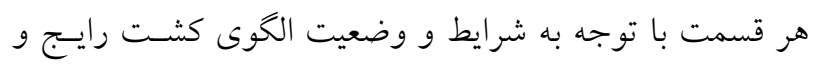

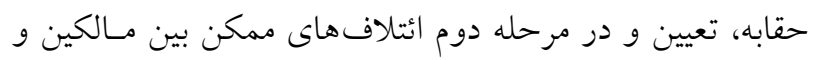

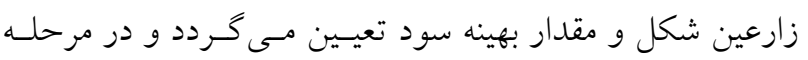

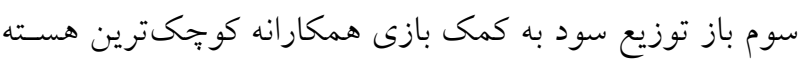

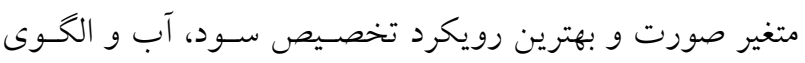
بهينه كشت تعيين مىشود.

\section{مواد و روشها - - ماد} بهمنظور سنجش كارايى مدل بيشنهادى، اراضسى تحـت بوشـش

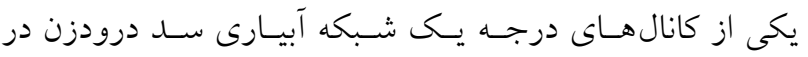
شهرستان مرودشت استان فارس، بهعنوان منطقـه مـورد مطالعـه

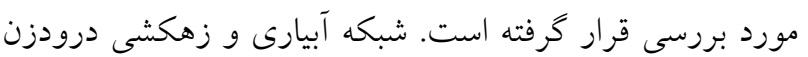

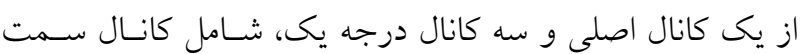

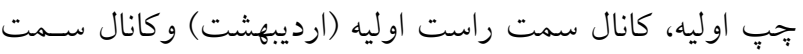

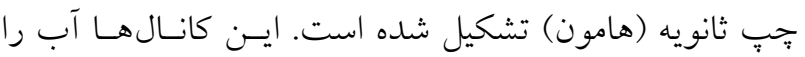

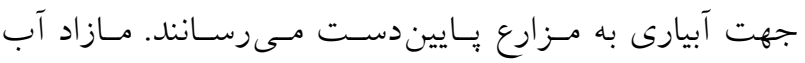

در تخصيص منابع آب و الحَـوى كثـت، ذينفعـان مختلفسى هـ

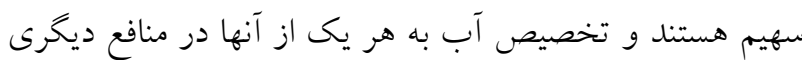

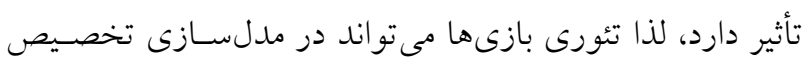

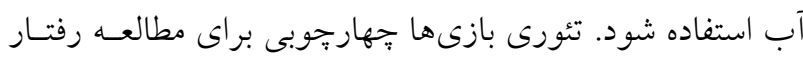

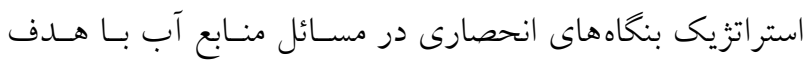
توسعه راهكارهاى مناسب است (9 و 19). بازى ها به دو دسـته

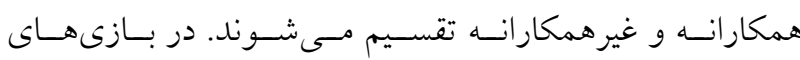
غيرهمكارانه بازيكنان مستقل تصميم مى گيرند. بـازى همكارانه.

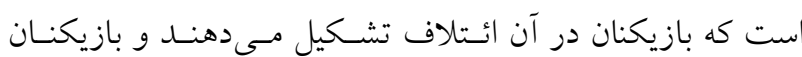

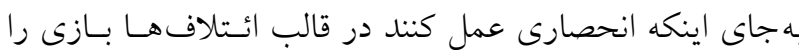
بيش مى برند. مطالعات زيـادى در كـاربرد تئسورى بـازى هـا در

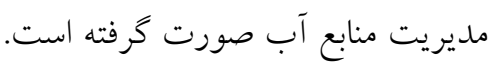

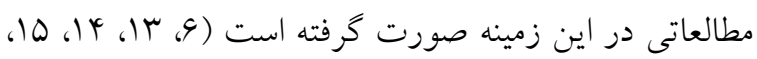

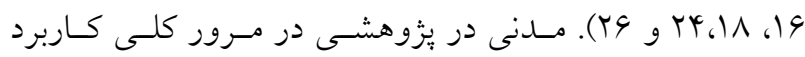

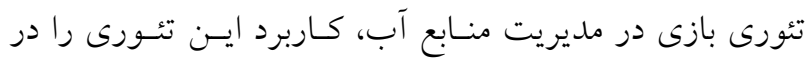
جֶهار گرووه طبقهبندى كرده اسـت: مـدلهـاى تخصسيص آب و

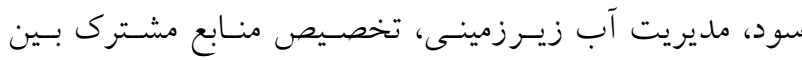

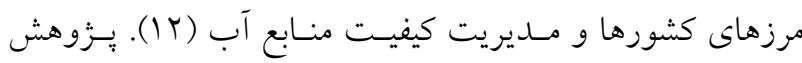

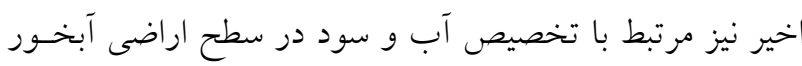

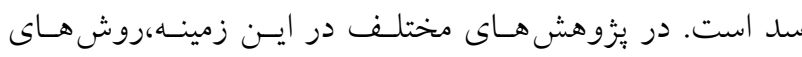

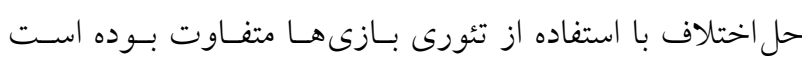

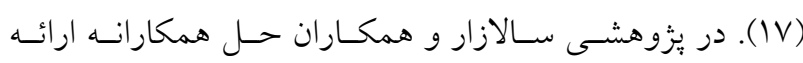

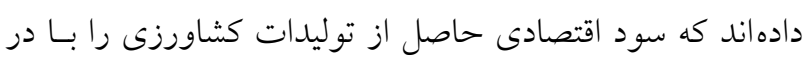
نظر كرفتن تأثيرات مخرب زيست محيطى متعـادل سـاختهانــا

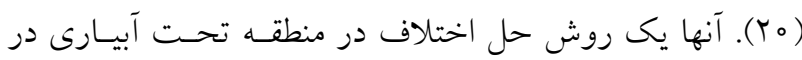

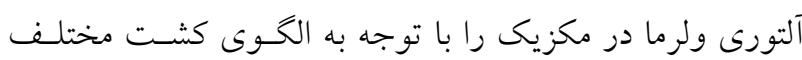

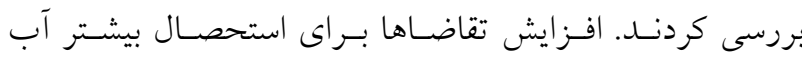

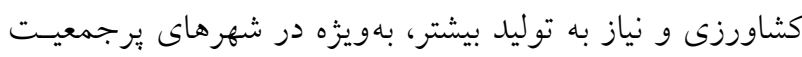
و توسـعه يافتـهـــ، سـبب افـزايش رقابـت و اختلافــات بسين

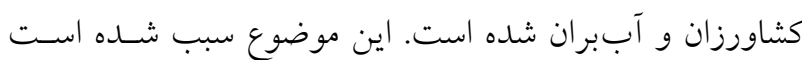

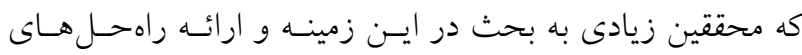

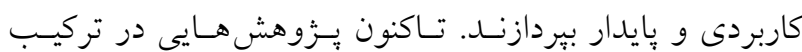




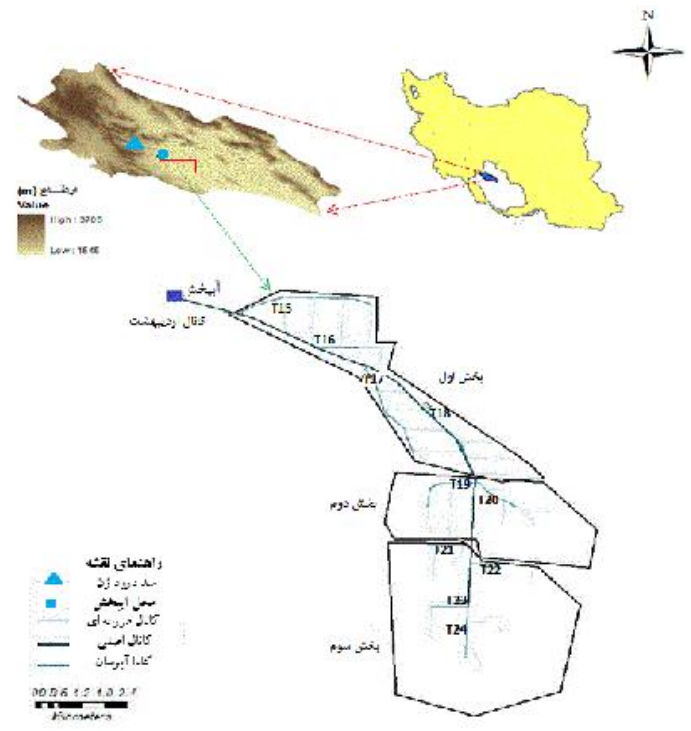

شكل ا. موقعيت منطقه مورد مطالعه و جزييات كانال ارديبهشت و كانالهاى باييندست آن در هر بخش

جدول ا. مشخصات هر بخش تحت يوشش كانال ارديبهشت

\begin{tabular}{|c|c|c|c|}
\hline محصولات عمده كشت شده در الكوى كشت رايج درهربخش & مساحت اراضى زيركشت(ha) & كانالهاى تأمين آب & بخش \\
\hline كَندم، جو، جِقندرقند، ذرت دانهاى، ذرت علوفهاى و برنج & $T \circ Y T / D$ & $|\wedge \mathrm{T} ،| \vee \mathrm{T}_{6}|\& \mathrm{~T} ،| \otimes \mathrm{T}$ & 1 \\
\hline گندم، جو، ذرت دانهاى، ذرت علوفهاى و برنج & $1 \mathrm{VV} 9 / 0$ & $\mathrm{r} \circ \mathrm{T}, 19 \mathrm{~T}$ & r \\
\hline كندم، جو، جِقندرقند، ذرت دانهاى، ذرت علوفهاى & TlO。 & YYTYM T,TYT,KIT & r \\
\hline
\end{tabular}

مرحله در شكل (Y) ارائه شده است.

\section{مدل برنامهريزى خطى فازى بهينهسازى الكوى كشت} درمسائل تصميم گيرى معمولى، جواب بهينهاى از مسئله با توجه به تابع هدف و محدوديتهاى موجود در نيازها و منـابع تعيسين

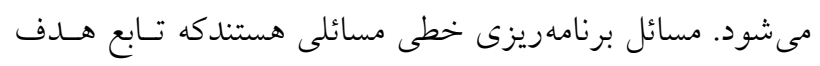

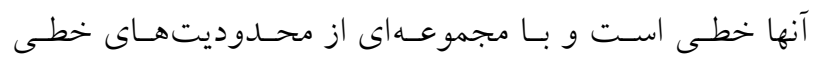
بهينهازى مى شوند. با توجه به عدم قطعيت و عدم صراحت در دنياى واقعى و تصميم كيرىها، ضرايب توابع و محدوديتها بـا

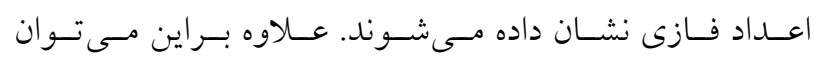
محدوديت ها را با روابط عدم تساوى فازى نشان داد (YV). ايسن روابط بهصورت زير است:

$\operatorname{Min} \tilde{f}(x)=\tilde{C} x$

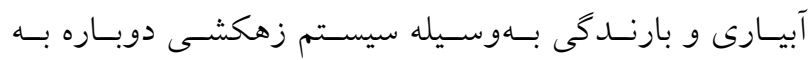

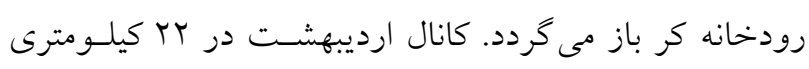
از سد درودزن از آب يخش منشعب مى شود و ده كانال درجه سه را آبرسانى مى كند. موقعيت منطقـه مـورد مطالعـه، كانـال

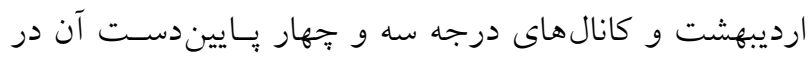
شكل( (1) نشان داده شده است. مجموعة اين كانالهـا اراضسى

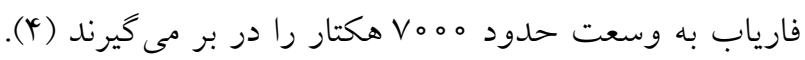
در اين يزوهش ميزان حقابه هر يـك از بخـش هــاى مختلـف براساس معيار عدالت تعيين شده است. مساحت بخـش هــاى مختلف و كانالهـاى درجـهـ دو موجـود در آنهـا و همجنــين وضعيت الخوى كشت فعلى هـر بخـش براسـاس شــرايط و ويزگ كى هاى خاص هر بخش در جدول (1) آورده شده اسـت.

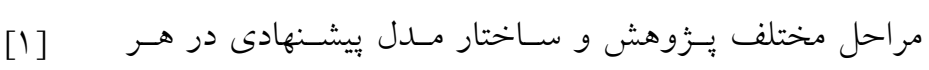




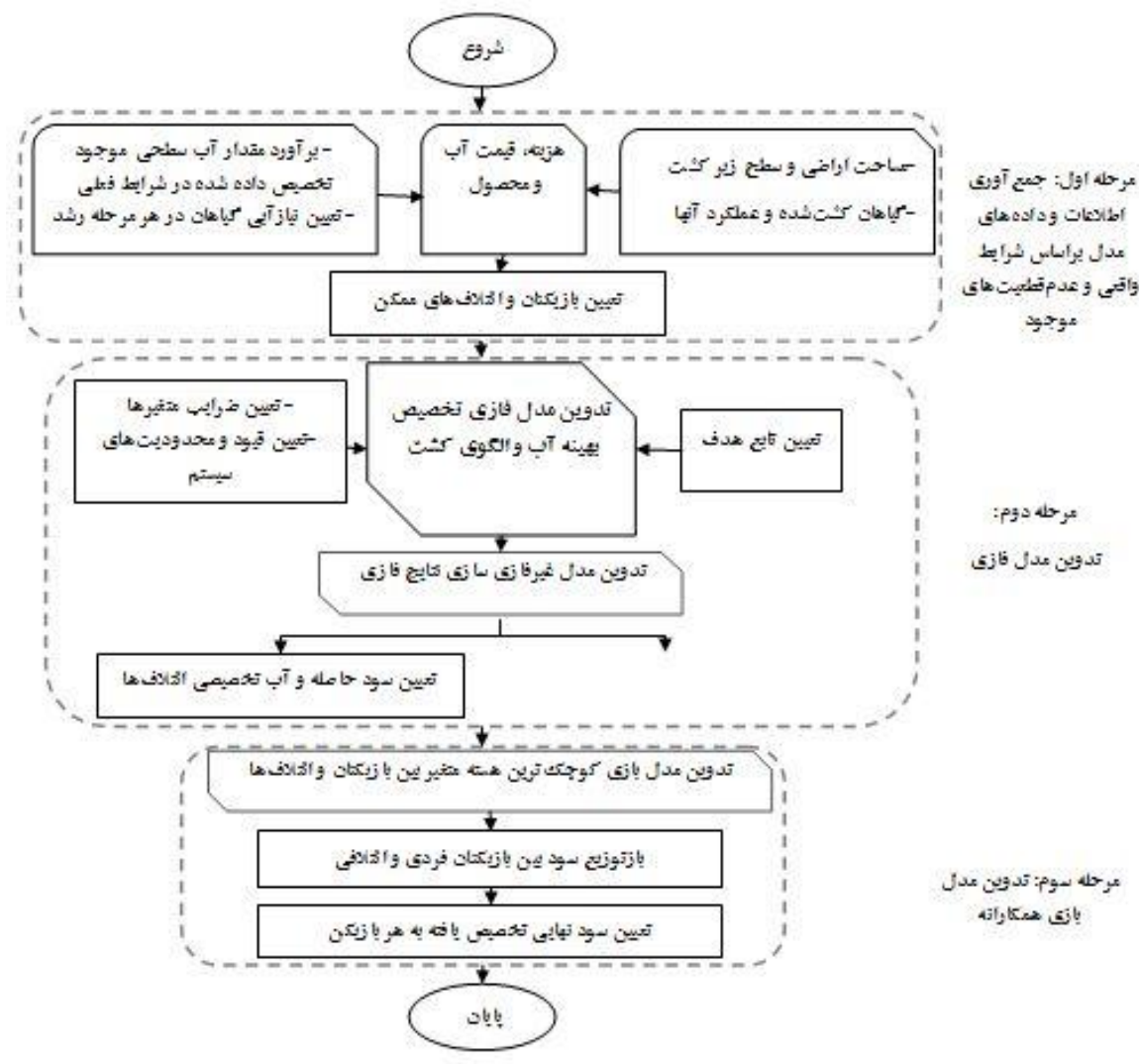

شكل r. ساختار مدل بيشنهادى و مراحل مختلف آن

توسط محققسين مختلـف ارائسه كرديــده اسـت. تانكـا و اسـاى

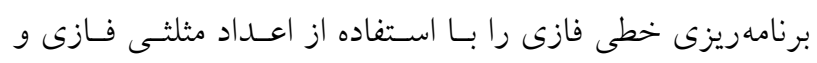

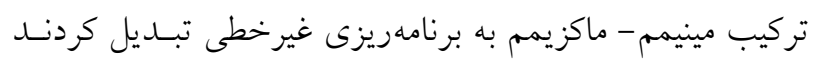

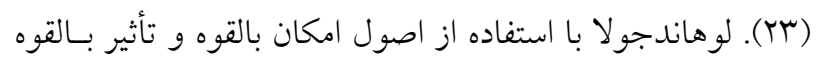

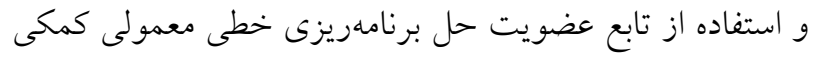

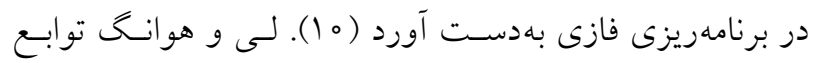

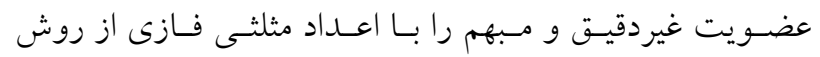

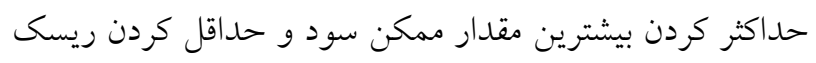

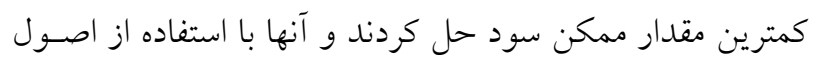

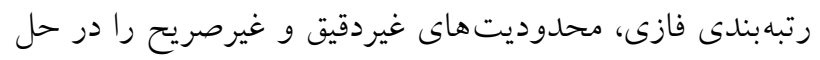

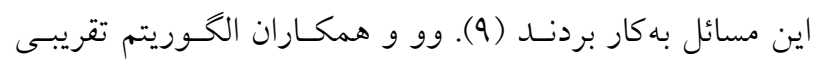

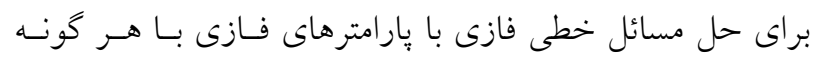

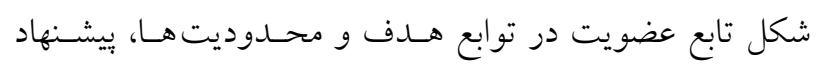

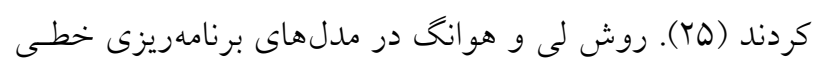

s.t. $x \in X_{d}, X_{d}=\{x \mid \tilde{A} x \tilde{\leq} \tilde{b}, x \geq 0\}$

بهطورى كه در معادلات بـالا، فازى است. فازى مثلثى با تابع عضويت خطى نامتقارن ( Triangular fuzzy

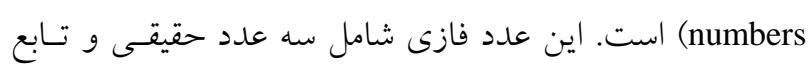
عضويت آن بهصورت زير تعريف مىشود: $\mu_{\tilde{a}}(x)= \begin{cases}\max \left\{0,1-\frac{a_{m}-x}{a}\right\}, & x \leq a_{m} \\ \max \left\{0,1-\frac{x-a_{m}}{\bar{a}}\right\}, & x>a_{m}\end{cases}$ در اين معادله a عدد اصلى a g a a

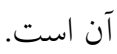

معمولاً براى حل مسائل برنامهريزى خطى فازى، ابتــا آنها را به مسائل خطى يا غيرخطى كلاسيك تبـديل مسى كنـــ (Y) (Y).

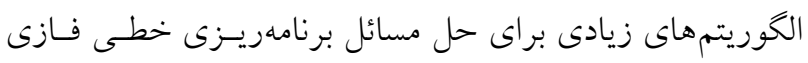


در اين روابط، عمق آبيـارى برحسبب سـانتى متـر، Ea

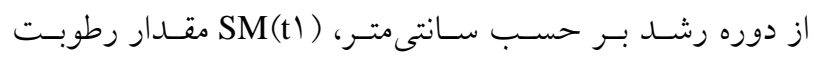

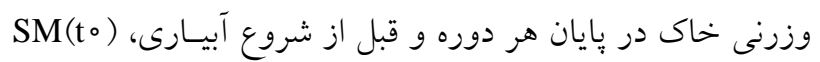

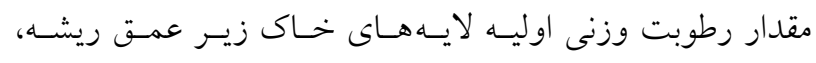

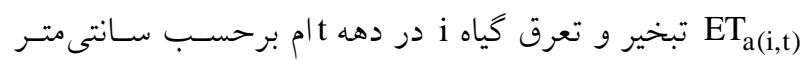

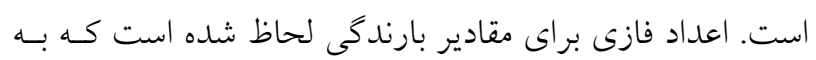

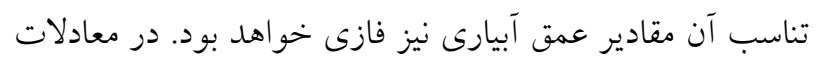

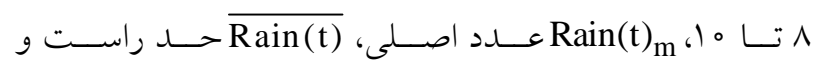
Rain(t)

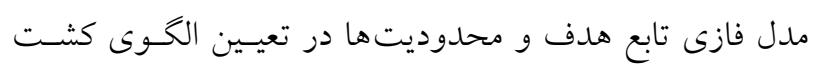
بهينه به صورت زير بيان مىشود:

$\operatorname{Max} \tilde{Z}=\sum_{\mathrm{i}=1}^{\mathrm{nc}}\left[\left(\tilde{\mathrm{Y}}_{\mathrm{a}(\mathrm{i})} \times \tilde{\mathrm{P}}_{\mathrm{c}(\mathrm{i})}-\tilde{\mathrm{C}}_{\mathrm{i}}-\tilde{\mathrm{R}}_{\mathrm{i}} \times \mathrm{P}_{\mathrm{w}}\right) \mathrm{A}_{\mathrm{i}}\right]$

$\sum_{i=1}^{n c}\left(A_{i}\right)_{s} \leq A$

$\sum_{\mathrm{i}=1}^{\mathrm{nc}} \mathrm{IR}_{\mathrm{i}} \mathrm{A}_{\mathrm{i}} \leq(\mathrm{TAW})$

$\mathrm{A}_{\mathrm{i}} \leq \mathrm{A}_{\max (\mathrm{i})}$

$A_{i} \geq A_{\min (i)}$

$\mathrm{A}_{\mathrm{i}} \geq$ 。

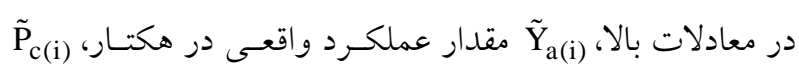

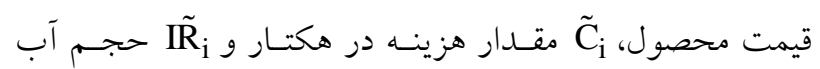

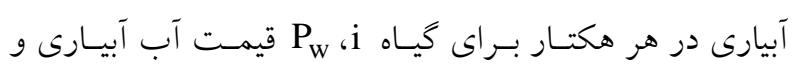

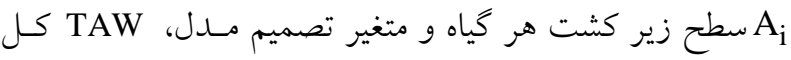
آب در دسترس، A كل سطح قابـل كشـت بهترتيب حداكثر و حداقل سطح زير كشت است.

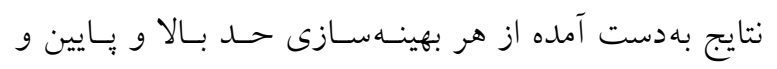

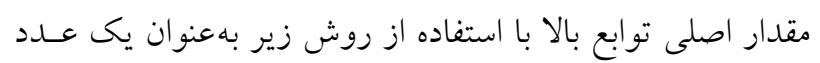
قطعى حاصل از مدل فازى تبديل مىشود:

$\operatorname{MaxZ}_{1}=\sum_{\mathrm{i}=1}^{\mathrm{nc}}\left[\left(\mathrm{Y}_{\mathrm{a}(\mathrm{i}) 。}{ }^{\mathrm{R}} \times \mathrm{P}_{\mathrm{c}(\mathrm{i}) 。}{ }^{\mathrm{R}}-\mathrm{C}_{\mathrm{i} 。}^{\mathrm{R}}-\mathrm{IR}_{\mathrm{i} 。}^{\mathrm{R}} \times \mathrm{P}_{\mathrm{w}}\right) \mathrm{A}_{\mathrm{i}}\right]$

$\operatorname{Max} Z_{Y}=\sum_{i=1}^{n c}\left[\left(Y_{a(i) 。}{ }^{L} \times P_{c(i) 。}{ }^{L}-C_{i 。}{ }^{L}-I_{i^{\circ} \circ}^{L} \times P_{W}\right) A_{i}\right]$

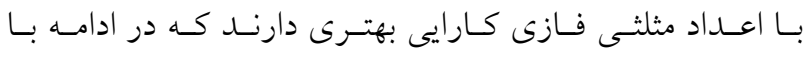

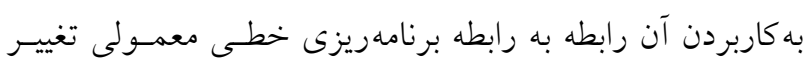
داده خواهد شد:

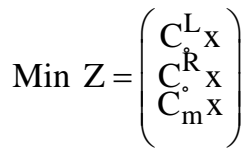

s.t. $x \in X_{d}=\left\{\begin{array}{l}A_{\beta}^{L} x \leq b_{\beta}^{L}, \\ A_{\beta}^{R} \leq b_{\beta}^{R}, \\ A_{m_{x} \leq b_{m}}^{R},\end{array}\right.$

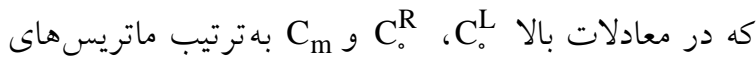
كران بالا و بايين و عدد اصلى اعداد فازى تابع هدف و و بهابه بهمين ترتيب

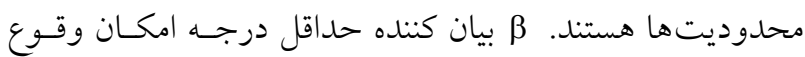

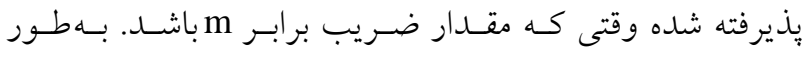

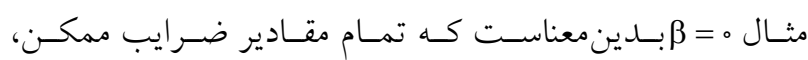
محدوديتها را قانع مى كند. بدون اين كه عموميت مسـأله تغييـر

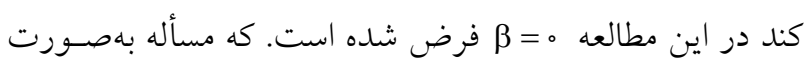
زير تغيير مى كند:

Min $Z=\left(\begin{array}{l}C_{o}^{L} x \\ C_{\circ}^{R} x \\ C_{m}^{R}\end{array}\right)$

s.t. $x \in X_{d}=\left\{\begin{array}{c}A_{\tilde{R}}^{\mathrm{L}} \mathrm{x} \leq \mathrm{b}^{\mathrm{L}}, \\ \mathrm{A}_{\circ}^{\mathrm{R}} \mathrm{x} \leq \mathrm{b}_{\circ}^{\mathrm{R}}, \\ \AA_{\circ} \mathrm{x} \leq \mathrm{b}_{\circ}, \\ \mathrm{x} \geq 0\end{array}\right.$

در مدل بهينه سازى تخصيص آب و الخَـوى كشـت، مقـدار

بارش سالانه با استفاده از بيشبينى تخمسين زده مسى شـود و يـا

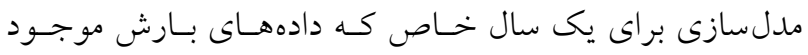

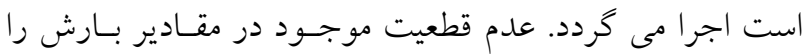

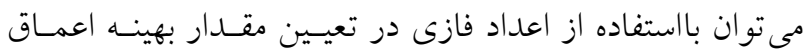
آبيارى با استفاده از معادلههاى زير در نظر كرفت:

$\mathrm{IR}_{(\mathrm{i}, \mathrm{t}) \mathrm{m}} \times \mathrm{Ea}=\mathrm{SM}\left(\mathrm{t}_{1}\right) \times \operatorname{Root}_{(\mathrm{i}, \mathrm{t}+1)}-\mathrm{SM}\left(\mathrm{t}_{\mathrm{o}}\right)$

$\times \operatorname{Root}_{(\mathrm{i}, \mathrm{t})}-\operatorname{Rain}(\mathrm{t})_{\mathrm{m}}+\mathrm{ET}_{\mathrm{a}(\mathrm{i}, \mathrm{t})}$

$\left(\mathrm{IR}_{(\mathrm{i}, \mathrm{t}) \mathrm{m}}+\overline{\mathrm{IR}_{(\mathrm{i}, \mathrm{t})}}\right) \times \mathrm{Ea}=\mathrm{SM}\left(\mathrm{t}_{1}\right) \times \operatorname{Root}_{(\mathrm{i}, \mathrm{t}+1)}$

$-S M\left(t_{0}\right) \times \operatorname{Root}_{(i, t)}-\left(\operatorname{Rain}\left(t_{m_{m}}+\overline{\operatorname{Rain}(t)}\right)+E T_{a(i, t)}\right.$

$\left(\mathrm{IR}_{(\mathrm{i}, \mathrm{t}) \mathrm{m}}-\mathrm{IR}_{(\mathrm{i}, \mathrm{t})}\right) \times \mathrm{Ea}=\mathrm{SM}\left(\mathrm{t}_{\mathrm{t}}\right) \times \operatorname{Root}_{(\mathrm{i}, \mathrm{t}+\mathrm{l})}$

$-\mathrm{SM}\left(\mathrm{t}_{\mathrm{o}}\right) \times \overline{\operatorname{Root}_{(\mathrm{i}, \mathrm{t})}}-\left(\operatorname{Rain}(\mathrm{t})_{\mathrm{m}}-\underline{\operatorname{Rain}(\mathrm{t})}\right)+\mathrm{ET}_{\mathrm{a}(\mathrm{i}, \mathrm{t})}$ 
جدولr. مقادير ضرايب و پِارامترهاى مختلف مدل بهينهسازى فازى الكوى كشت و تخصيص آب

\begin{tabular}{|c|c|c|c|c|c|c|}
\hline (تومان بر كيلو گرم) & (هزار تومان در هكتار) & (تن در هكتار) & تبخير و تعرق در فصل رشد & (هزآ آب آبيارى مورد نياز & كاربرد(.) & 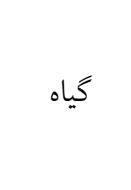 \\
\hline$r 90$ & $(11 r \Lambda, g \circ, g \Delta \circ)$ & $(V, g, \circ / \Delta)$ & Vre/o & $(11 / r g / / 0,1 / r)$ & 90 & 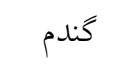 \\
\hline$\left(r Y_{0}, Y_{\circ}, g^{\circ}\right)$ & $\left(\mid \circ r, g r \circ g, r r_{0}\right)$ & $(\Delta, \circ / V, \circ / \Delta)$ & $991 / \mathrm{V}$ & $(9 / /, \circ / 0, \circ / \Lambda)$ & 90 & جو \\
\hline$(1 \circ 0,10,0)$ & $(Y \Lambda \circ \circ, \wedge \circ 0, Q 0 \circ)$ & $(r r, r / \Delta, \Delta / \Delta)$ & $q \pi r / q$ & $(10 / 0,1 / V, Y / T)$ & 90 & جقندرقند \\
\hline$\left(r \Delta \circ, \omega_{0}, \omega_{0}\right)$ & $\left(990, \wedge \Delta, \mid \mu_{0}\right)$ & $(9, Y, 1 / 0)$ & VG. & $(1 / / r, 1 / 1,1 / \Gamma)$ & 90 & ذران \\
\hline$(10,|0,| \circ)$ & $(1 r \Delta \circ, r \omega \circ, \quad r \circ \circ)$ & $(\Delta \circ, \Delta, \Delta)$ & 994 & $(11 / 9,1 / \pi, 0 / 9)$ & 90 & غلرت \\
\hline $\begin{array}{c}g, 00000) \\
(1000\end{array}$ & $\begin{array}{c}g \wedge \Delta \circ g \mid r \circ \circ) \\
(Y Y \wedge \circ 0\end{array}$ & $(0,1,1)$ & 901 & $(\Gamma \Gamma / \Psi, \Gamma / V, \Gamma / Q)$ & ro & برنج \\
\hline
\end{tabular}

استفاده شده است. بازى به كار كرفته شده در اين يزوهش، بازى

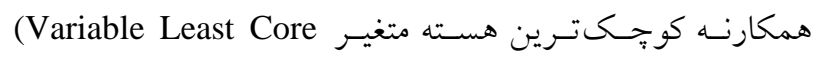
استكه بازتوزيع سـود در يـك بـازى دوطرفـه صـورت Game) مى كيرد. همجنين طرفين و بازيكنان در ائتلاف عقلايى هستند و مجموع سودهاى تخصيص داده شده به بازيكنـان برابـر بـا كـل

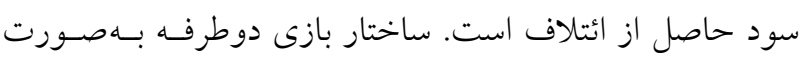
زير است:

Min $\varepsilon$

s.t

$\varphi_{1}-\varepsilon \geq v_{1}$

$\varphi_{\Upsilon}-\varepsilon \geq \mathrm{v}_{\Upsilon}$

$\varphi_{1}+\varphi_{r} \equiv v_{1 r}$

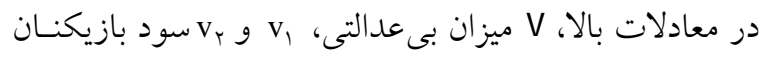
ا و r در صورتى كه بهصـورت مسـتقل عمـل كنــد،

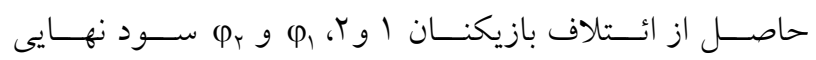

$$
\operatorname{MaxZ}_{r}=\sum_{\mathrm{i}=1}^{\mathrm{nc}}\left[\left(\mathrm{Y}_{\mathrm{a}(\mathrm{i}) \mathrm{m}} \times \mathrm{P}_{\mathrm{c}(\mathrm{i}) \mathrm{m}}-\mathrm{C}_{\mathrm{im}}-\mathrm{IR}_{\mathrm{im}} \times \mathrm{P}_{\mathrm{w}}\right) \mathrm{A}_{\mathrm{i}}\right]
$$

محدوديتهاى مدل هاى بهينهسازى ارائه شده در معادلات اتا 19، همان محدوديتهاى بإ تا 19 است. اهميت نسبى يا وزن هر يك از اهداف فـازى بـا استفاده از روش خطى وزنسى بــا مى شود و خواهيم داشت: $\operatorname{Maxf}=\omega, \sum_{\mathrm{i}=1}^{\mathrm{nc}}\left[\left(\mathrm{Y}_{\mathrm{a}(\mathrm{i}) \circ}{ }^{\mathrm{R}} \times \mathrm{P}_{\mathrm{c}(\mathrm{i}) \circ}{ }^{\mathrm{R}}-\mathrm{C}_{\mathrm{i} 。}^{\mathrm{R}}-\mathrm{IR}_{\mathrm{i} 。}^{\mathrm{R}} \times \mathrm{P}_{\mathrm{w}}\right) \mathrm{A}_{\mathrm{i}}\right]+$ $\omega_{r} \sum_{i=1}^{n c}\left[\left(Y_{a(i) 。}{ }^{L} \times P_{c(i) 。}{ }^{L}-C_{i 。}^{L}-I_{i 。}^{L} \times P_{w}\right) A_{i}\right]$ $+\omega_{r} \sum_{i=1}^{n c}\left[\left(Y_{a(i) m} \times P_{c(i) m}-C_{i m}-I_{i m} \times P_{w}\right) A_{i}\right]$

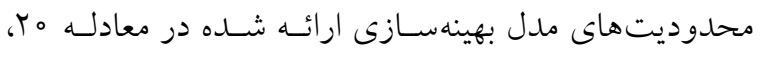
همان محدوديتهاى بان تا 19 است.

مدل بازى همكارانه در اين بززوهش براى اولين بار تخصيص سـود و آب در تعيسين

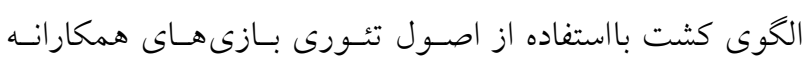




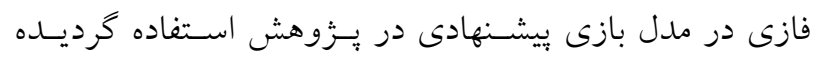

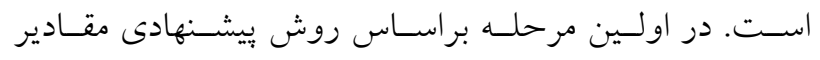

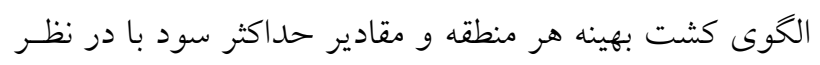

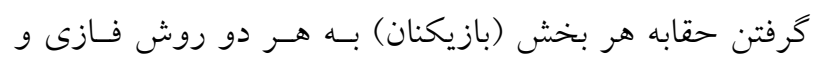

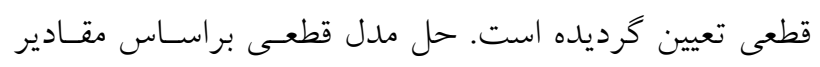

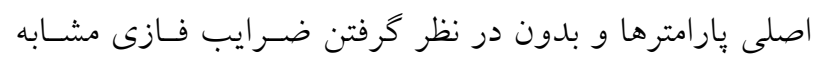

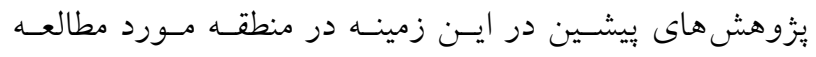

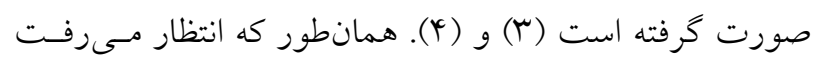

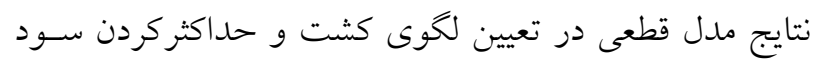
حاصل متفاوت خواهد بود. ولى نتايج اين مدلها قابل اعتماد

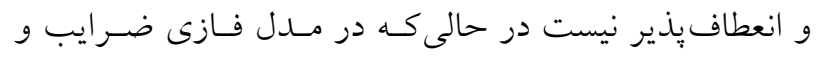

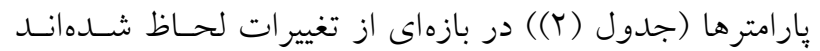

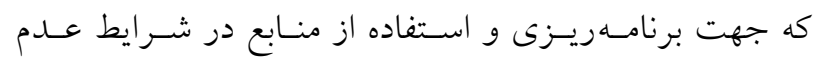

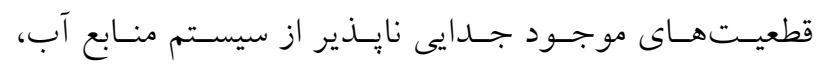
مناسبتر هستند. بهعنوان بخشى از نتايج اين قسـمت مقــادير

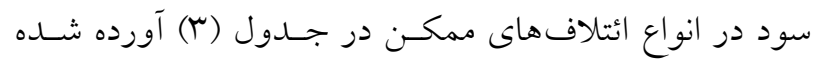

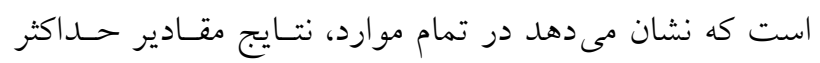

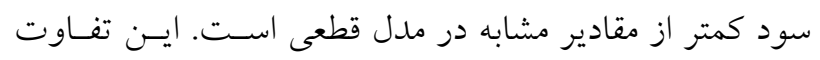

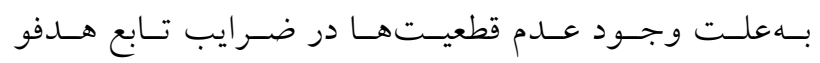

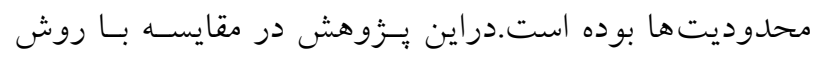

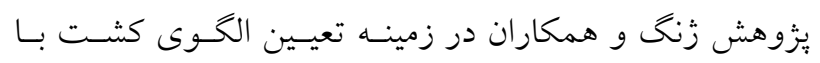

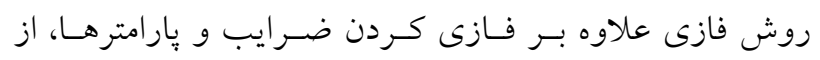
رويكرد تئورى بازىها نيز استفاده شده است.

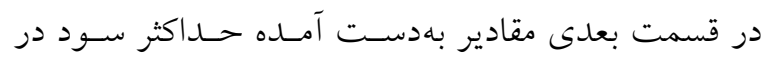

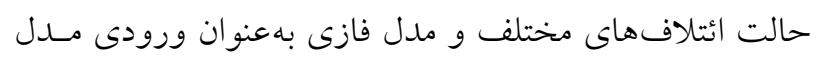

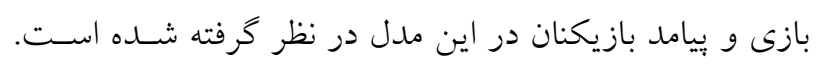

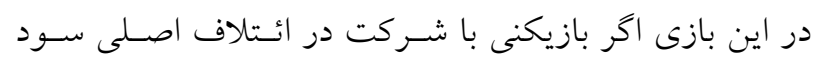

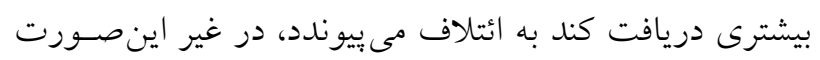

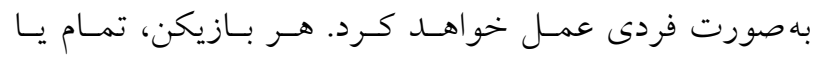
قسمتى از حقابه خود را در شركت در ائتلاف به كار مى گيــرد

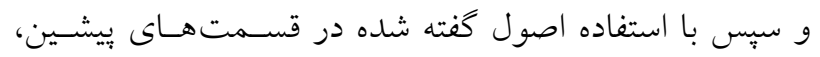

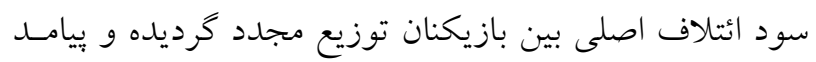

تخصيص داده شده به هر بازيكن است. در اين مرحلـه از حـل

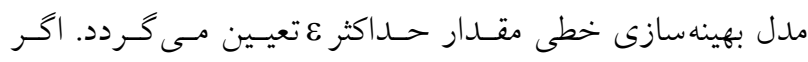

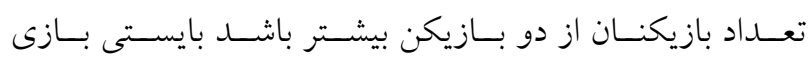

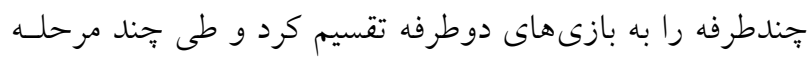

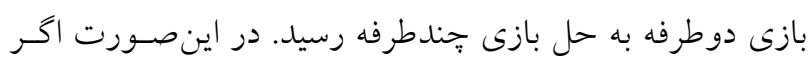

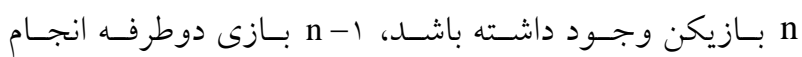
خواهد شد كه الكوريتم آن به صورت زير است:

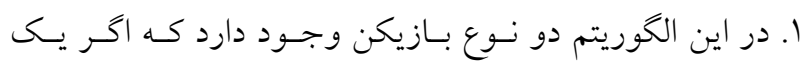

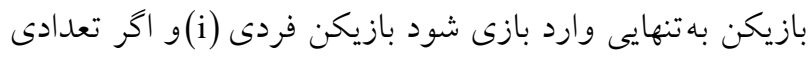

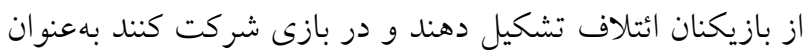

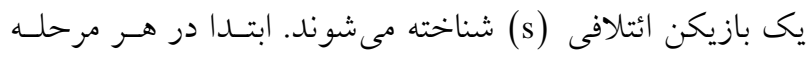

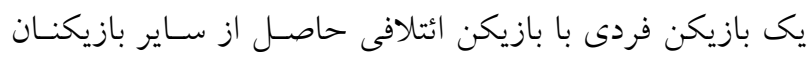

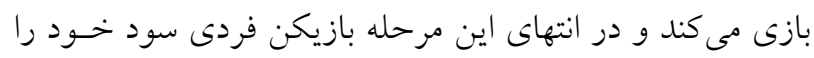
دريافت مى كند.

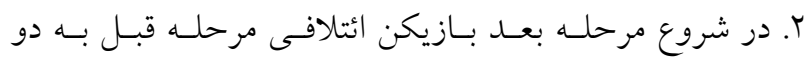

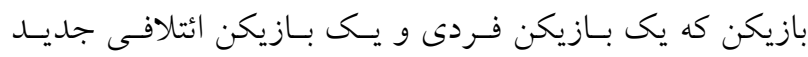

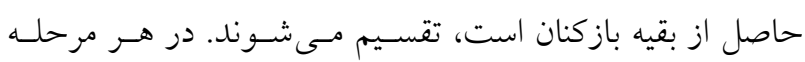

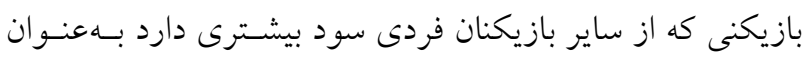
بازيكن فردى انتخاب مىشود.

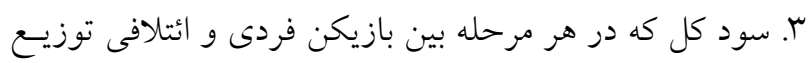

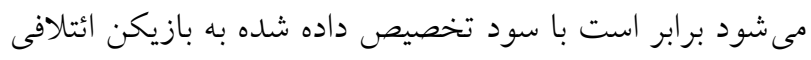

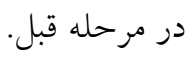
با. نهايتاً، در آخرين مرحله دو دو بازيكن فردى با هم بازى مى كنند و سود نهايى آنها تعيين مى خردد.

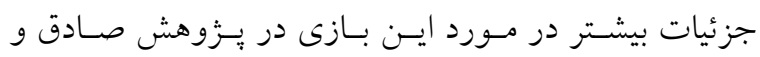

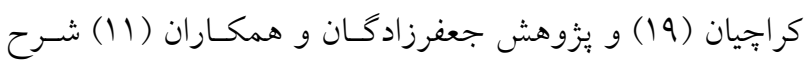

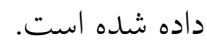

\section{نتايج و بحث}

در اين بخش نتايج مدل ارائه شده فازى نشان داده شده است

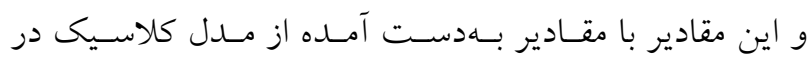

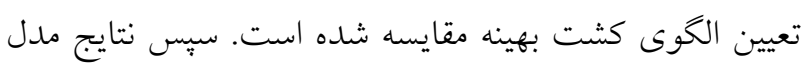


جدولr. سود تمام بازيكنان و ائتلافهاى ممكن در مدل قطعى و فازى

\begin{tabular}{|c|c|c|c|c|c|c|c|}
\hline \multicolumn{3}{|c|}{ 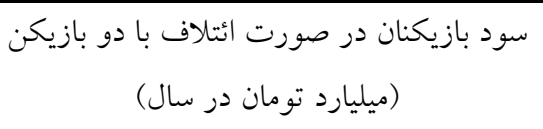 } & \multicolumn{3}{|c|}{ سود بازيكنان در صورت عدم شركت در } & \multirow{2}{*}{ 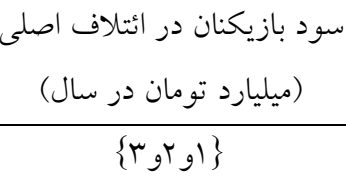 } & \\
\hline$\{r, r\}$ & $\left\{r_{g},\right\}$ & $\{r, \mid\}$ & $r$ & $r$ & 1 & & \\
\hline$V / T \circ D$ & $9 / 410$ & N/rTO & $r / \Delta V$ & $r / 410$ & $\Delta / r \circ \psi$ & $\mid r / A T \Delta$ & مدل قطعى \\
\hline$Q / V D G$ & $9 / 99 \mathrm{~V}$ & $9 / \pi \Delta 9$ & $r / 190$ & $r / 490$ & $r / Q V G$ & QVVYY & مدل فازى \\
\hline
\end{tabular}

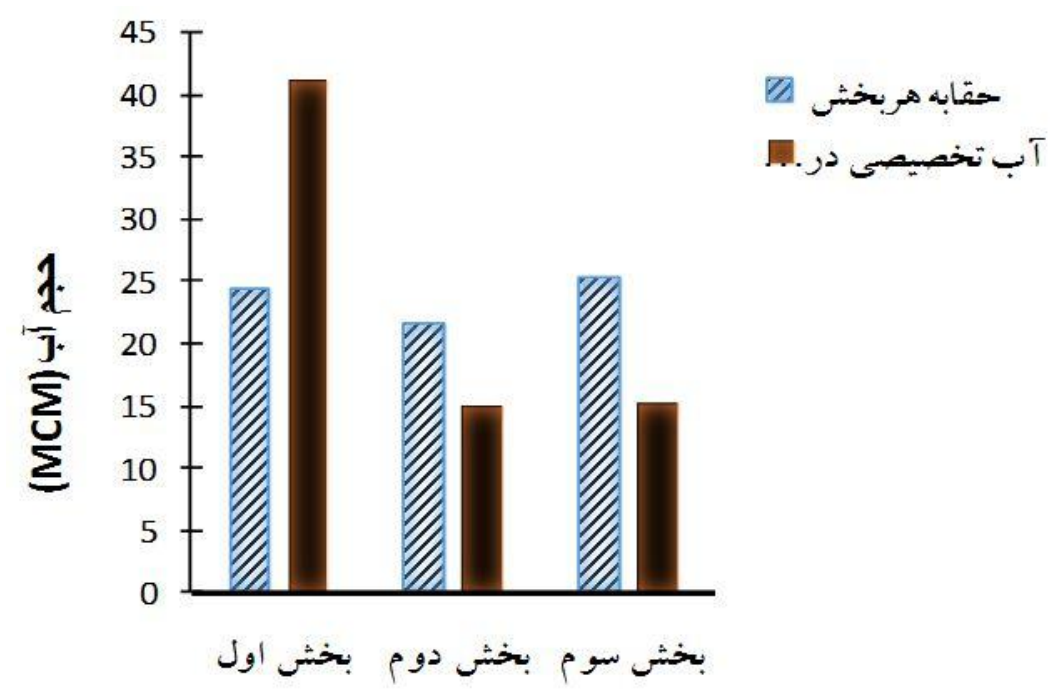

شكل r. مقايسه مقادير حقابه و آب تخصيص داده شده به هر بخش در ائتلاف اصلى

يار امترهاى هر بخش در جــدول (Y) تعيسين شـده اسـت. نتـايج حاصل نشان مىدهد كه در بخشش اول، با توجه محدوديتهـا و مقدار سود حاصل از كشـت محصـولات مختلـف، سـطح زيـر كشت گياهان گندم، ذرت دانهاى و برنج افزايش مىيابد. بر ايسن اساس هر كدام از بازيكنان در صورت شركت در ائتلاف اصسلى مقادير سود بيشترى را درمقايسه با حالتى كه بـهــورت فـردى

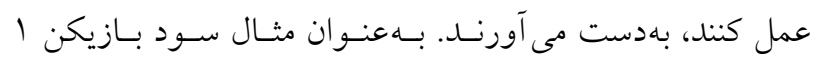
r/OV9 بخش اول) در صورتى كه بهصورت انفرادى عمل كنــ ميليارد تومان در سال است (جدول r) و در صورت شركت در ائتلاف به r/VVY ميلياردتومان در سال خواهد بـود (جــدول ؟Y). بههمين ترتيب ساير بازيكنان نيـز افـزايش سـود داشـتهانـد. در

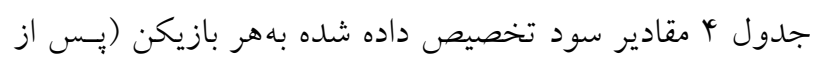

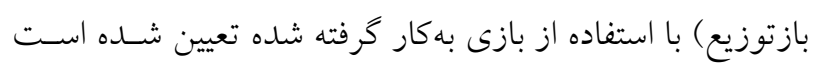
كه همانطور كه كفته شد مقادير سود تخصيص داده شده به هر
نهايى هر بازيكن ( سود نهايى تخصيص داده شده به هر بخش)

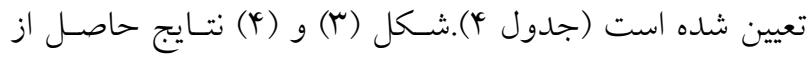
شكل گيرى ائتلاف اصلى را نشان مي دهــد. در شـكل ب مقــادير آب تخصيصى و حقابه هر بازيكن قبل و بعـد از بـازى بـا هـم

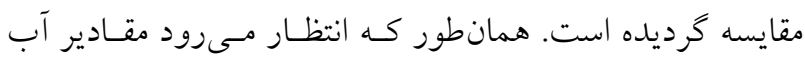

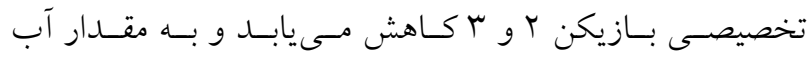
تخصيصى بـازيكن ا كـه ظرفيـت سـودآورى بيشـترى را دارد، افزوده شده است. الخوى بهينه كشت يس از شكل گيرى ائستلاف

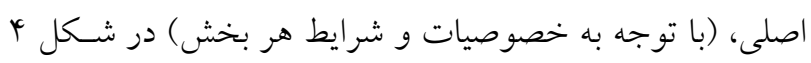
نشان داده شده است. بهطور كلى همانطور كه در قسـمتهـاى بيشين به آن اشاره كرديد مدل بازى همكارانـه آب بيشـترى بـهـ بخشى كه بازده و يتانسيل توليد بيشتر دارد تخصيص مسىدهـد. تفاوتهاى بخش هاى مختلف براساس ميزان دسترسى به منـابع

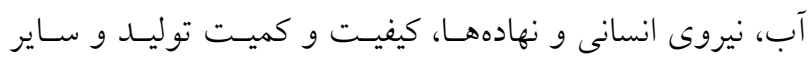


نشريه علوم آب و خاك (علوم و فنون كشاورزى و منابع طبيعى) / سال بيستم / شماره هفتادو ششم / تابستان هوس|

جدول F. سود نهايى تخصيص داده شده به هر بخش (بازيكن)

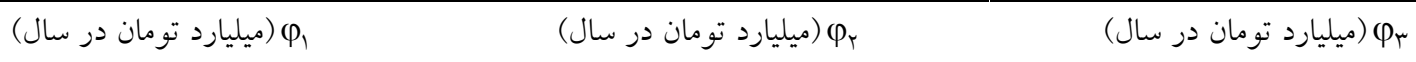
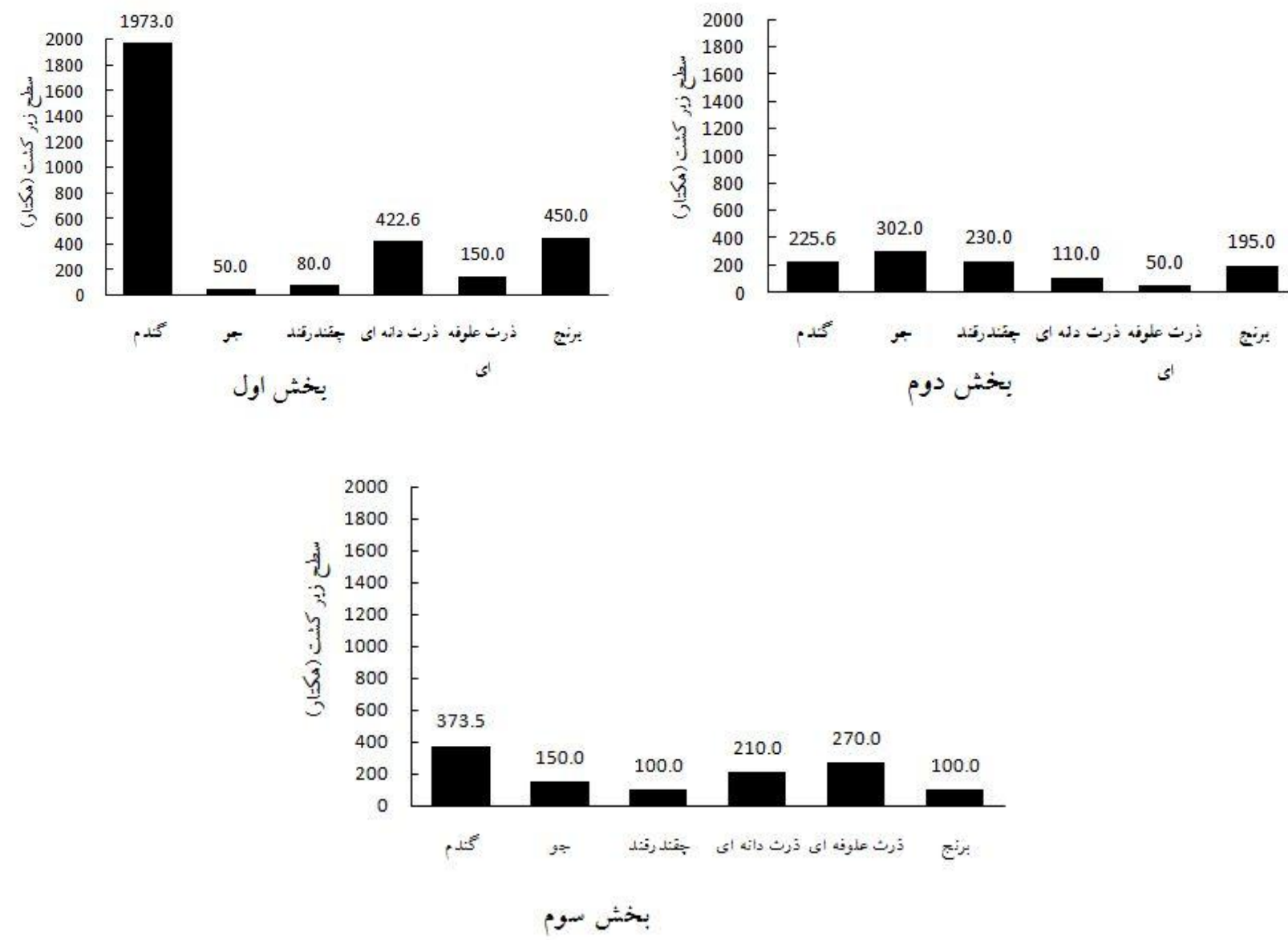

شكل f) سطح زير كشت گياهان مختلف در الكوى كشت در ائلاف اصلى (ha)

اسـتراتزهاى ذينفعـان و ذىمـــخلان مسى يـردازد. در تحقيقـات ييشين از ايسن اصـول در مـديريت آبيـارى جهـت تحليـلهـاى

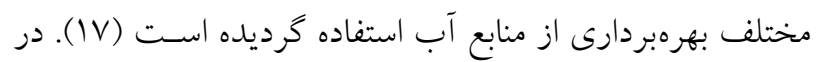
اين يزوهش نيز با تحليل مقادير حقابه باى بخش هاى مختلف و تفاوتهاى موجود در ساختار كشاورزى هر بخش از اصول اين نظريه در تخصيص و بازتوزيع سود اسـتفاده گرديـــ كـه نتـايج نشان داد كه استفاده از اين اصول به افزايش سود خـالص تمـام بخش ها خواهد انجاميد. بهطـور كلى روش بيشــهادى در ايسن
بخش يـس از تشـكيل ائستلاف افـزايش مسىيابــ. سـودخالص بهصورت عادلانه و عقلايى بين بازيكنان از روش بازى حـداقل

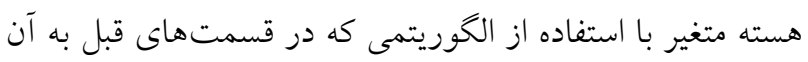
اشاره شده است باز توزيع گرديده است. بنابراين باتوجه به ايسن

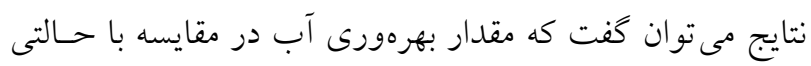

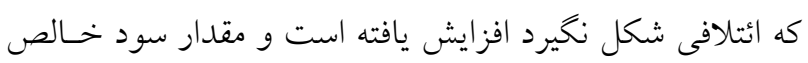
حاصل از كشت محصولات مختلف نيز افزايش خواهد يافت.

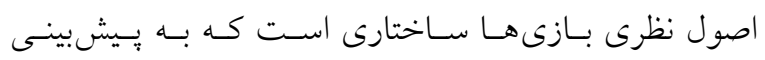


شركت كننده در ائتلاف، بهينـهــازى در هـر ائستلاف بـا هـدف دستيابى به حداكثر سود صورت گرفتـه اسـت. در مرحلـه بعـد، سود كل در روشى عقلايى و عادلانه بـا اسـتفاده از مـــل بـازى همكارانه كو جكىترين هسته متغير، سود بـازتوزيع شــده اسـت. نتايج نشان مى دهد كه در صورتى كه بازيكنان در ائتلاف شركت

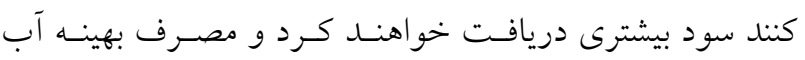
افزايش بيدا مى كند. اين قبيل بززوهش ها در مديريت آبيـارى بـه تصميم گيران و ذينفعان استفاده از روشهاى خلاقانه در استفاده از آب را بيشنهاد مى كند. در يـزّوهشهــاى آينـده، مسى تـوان از مدلهاى بويا و غيرخطى فازى و ساير اصـول نظـرى بـازى بـا توجه به عدم قطعيتهاى موجود در ضـرايب، محسدوديتهــا و ائتلاف ها استفاده كرد.همجنين مىتوان ساير مدلهـاى فـازى را جهت تخمين مقــادير اهـاف مختلـف، تعيسين ارزش و قيمـت

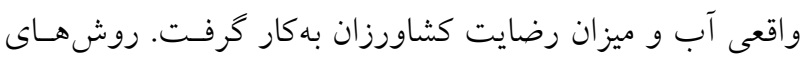
مختلف به كار كرفته شده در اين بزّوهش قابل تعمسيم بـه سـاير مسائل تصـميم گيـرى و برنامسهريـزى اسـت و مسىتـوان سـاير مدلهاى مرتبط دز اين زمينه را بهاين مدلها ارتباط داد.
مقالـه در مقايسـهـ بـاــا تحقيقـات مـرتبط در ايـن زمينـه، ديــــاه جديدى در تخصيص آب به بخشهـاى مختلـف كشـاورزى و تعيين الخوى بهينه كشت در منطقه مورد مورد بررسى قـرار داده است كه نتايج در مقايسه با نتايج مدلهاى بيشين قابليت اعمـال مسائل اجتماعى، رقابـت و همكـارىهـاى سـازنده را داشـهـه و تفاوتهاى ساختارى با تحقيقات كذشته دارد.

\section{نتيجه گيرى}

يكى از موضوعات مهم در زمينه مـديرت منـابع آب تخصسيص بهينه آب آبيارى بين آببران و كشتهاى مختلف است. در اين يزّوهش مدل هاى جديدى براساس اصول نظرى مجموعسههـاى فازى و اصول نظرى بازىهاى همكارانه ارائسه گرديــده اسـت و نتايج اين روش ها و مقايسه آنها با روشهاى قطعى و بيشين در مطالعهاى مـوردى در شـبكه آبيـارى درودزن فـارس مطالعـهـ و بررسى شده است. در روش بيشنهادى، مدل بهينهسازى تـأمين حداكثر سود اوليه، تخصيص آب و الكوى بهينه كشـت تـدوين شده و سيس در ائستلافهـاى مختلـف بـا توجـهـ بــه بازيكنـان

\section{منابع مورد استفاده}

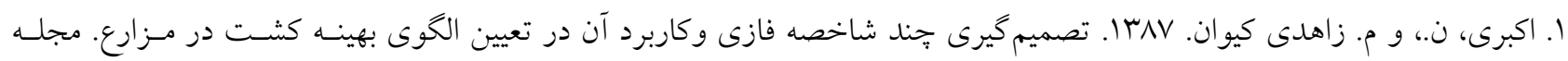

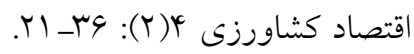

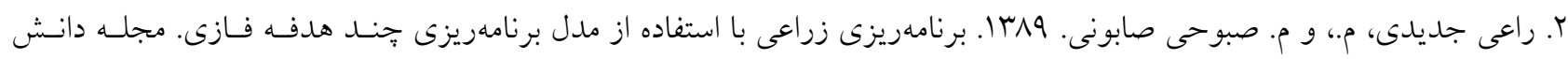

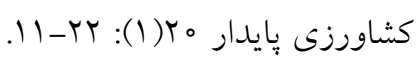

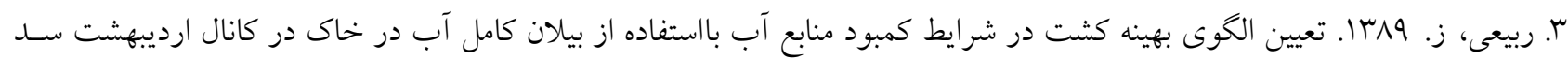

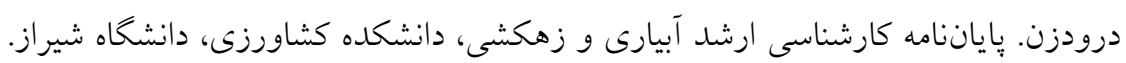

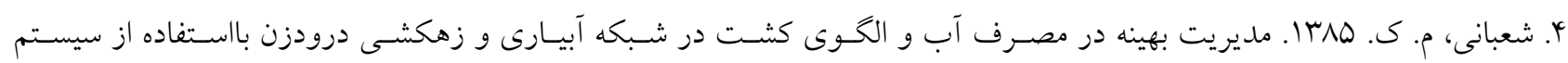

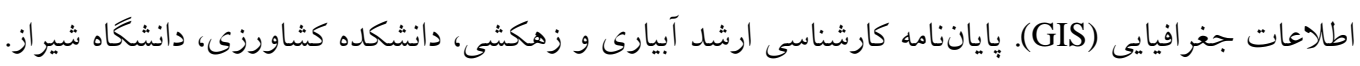

5. Aadland, A. and V. Kolpin. 2004. Erratum to Environmental determinants of cost sharing. J. Econo. Behav. \& Org. 55: $105-121$.

6. Ambec, S. and L. Ehlers. 2007. Sharing a river among satiable countries. Working Paper, GAEL and Université deMontréal.

7. Dai, Z. Y. and Y. P. Li. 2013. A multistage irrigation water allocation model for agricultural land-use planning under uncertainty. J. Agri. Water Manage. 129: 69-79.

8. Daneshvar Kakhki, M. 2009. The determination of optimal crop pattern with aim of reduction in hazards of environmental. J. Agri. and Bio. Sci. 4. 4(4): 305-310.

9. Lai, Y. J. and C. L. Hwang. 1992. A new approach to some possibilistic linear programming problems. J. Fuzzy Sets 
and Systems. 49: 121-133.

10. Luhandjula, M. K. 1987. Multiple objective programming problems with possibilistic coefficients. J. Fuzzy Sets and Systems. 21: 135-145.

11. Jafarzadegan, K., A. Abed-Elmdoust and R. Kerachian. 2013. A fuzzy variable least core game for inter-basin water resources allocation under uncertainty. J. Water Resour. Manage. 27: 3247-3260.

12. Madani, K. 2010. Game theory and water resources. J. Hydrology. 381(3-4): 225-238.

13. Mckinney, D. C. and R. L. Teasley. 2007. Cooperative game theory for transboundary river basins: the Syra Daryabasin. Proceedings of the World Environmental and Water Resources Congress, May, Florida.

14. Mahjouri, N. and M. Ardestani. 2011. Application of cooperative and non-cooperative games in large-scale water quantity and quality management: a case study. J. Environ. Monit Assess. 172(1-4): 157-169.

15. Nikoo, M. R., R. Kerachian and H. Poorsepahy-Samian. 2012. An interval parameter model for cooperative interbasin water resources allocation considering the water quality issues. J. Water Resour. Manag. 26(11): 3329-3343.

16. Niksokhan, M. H., R. Kerachian and M. Karamouz. 2009. A game theoretic approach for trading discharge Permitsin Rivers. J. Water Sci. Tech. 60(3): 793-804.

17. Podimata, M. and P. Yannopoulos. 2015. Evolution of game theory application in irrigation systems. Agriculture and Agricultural Science Procedia. 4: 271-281.

18. Poorsepahy-Samian, H., R. Kerachian and M. R. Nikoo. 2012. Water and pollution discharge permit allocation to agricultural zones: application of game theory and min-max regret analysis. J. Water Resour. Manag. 26: 42414257.

19. Sadegh, M. and R Kerachian. 2011. Water resources allocation using solution concepts of fuzzy cooperative games: fuzzy least core and fuzzy weak least core. J. Water Resour. Manag. 25(10): 2543-2573.

20. Salazar, R., F. Szidarovszky Jr. E. Coppola and A. Rojano. 2007. Application of game theory for a groundwater conflict in Mexico. J. Environ. Manage. 84(4): 560-571.

21. Sepaskhah, A. R. and B. Ghahraman 2004. The effects of irrigation efficiency and uniformity coefficient on relative yeild and profit for deficit irrigation. J. Biosys. Engineer. 87: 495-507.

22. Tanaka, H., T. Okuda and K. Asai. 1974. On fuzzy mathematical programming. J. Cybernetics. 3: 37-46.

23. Tanaka, H. and K. Asai. 1984. Fuzzy linear programming problems with fuzzy numbers. Fuzzy Sets and Systems. 13: 1-10.

24. Wang, L., L. Fang and K. W. Hipel. 2008. Basin-wide cooperative resources allocation. Eur. J. Oper. Res. 190(3): 798-817.

25. Wu, F., J. Lu and G. Zhang. 2006. A new approximate algorithm for solving multiple objective linear programming problems with fuzzy parameters. J. Applied Mathematic Comput. 174: 524-544.

26. Xuesen, L., W. Bende, R. Mehrotra, A. Sharma and W. Guoli. 2009. Consideration of trends in evaluating interbasin water transfer alternatives within a fuzzy decision making framework. Water Resour. Manag. 23: 3207-3322.

27. Zeng, X., S. Kang, F. Li, L. Zhang and P. Guo. 2010. Fuzzy multi-objective linear programming applying to crop area planning. Agricul. Water Manage. 98: 134-142.

28. Zorba, A. S., P. K. Tolikas and D. K. Tolikas. 2001. Application of game theory to the exploitation of an aquifer with pumping wells. Tech. Chronicle Sci. J. Tech. Champer of Greece. 1(2): $43-52$ (in Greek). 


\title{
Developing a Fuzzy Crop Pattern and Water Allocation Optimization Model Based on Cooperative Game Theory: A Case Study, Ordibehesht Canal at the Doroodzan Irrigation Network, Northwest of Fars Province in Iran
}

\author{
M. Omidvar ${ }^{1}$, T. Honar ${ }^{1}$, M. R. Nikoo ${ }^{2^{*}}$ and A. R. Sepaskhah ${ }^{2}$
}

(Received: Feb. 22-2015 ; Accepted : July 25-2015)

\begin{abstract}
At the river catchments, different strategies at the whole or different parts of the basin can be applied for water resources management. One of these strategies is optimal water allocation and crop pattern. In this study, an optimization model for water allocation and cropping pattern is presented based on the cooperative game theory. To measure the performance of the developed model, the cultivated area of Ordibehesht Canal in the Doroodzan irrigation network has been studied. First, using a fuzzy model and considering the fuzzy coefficients values in the objective function and constraints, the optimal crop pattern and allocated water has been determined for each crop. Second, benefits of stakeholder's coalitions have been determined by developing a cooperative game model and based on the structure and properties of the irrigation water distribution network and water rights of each part. Then, the total net benefit has been reallocated to the different stakeholder in a rational and equitable way using Least Core games. The results show that by allocating more water to the sectors with more potential production, more profits are generated and water productivity increases. For example when players cooperate together and form the grand coalition, the net benefit increases from 8.906 billion Tomans to 9.724 billion Tomans that show an increase in the economic productivity of water.
\end{abstract}

Keywords: Optimal cropping pattern, Optimal water allocation, Fuzzy model, Cooperative game.

1. Dept. of Water Eng., Faculty of Agriculture, Shiraz Univ., Shiraz, Iran.

2. Dept. of Civil and Environ. Eng., Faculty of Eng., Shiraz Univ., Shiraz, Iran.

* Corresponding Author, Email: nikoo@ shirazu.ac.ir 